\title{
A CLARIFICATION OF THE DISTINCTIONS BETWEEN PLEUROTHALLIS TALPINARIA AND PLEUROTHALLIS TRIMEROGLOSSA (ORCHIDACEAE: PLEUROTHALLIDINAE) AND AN ALLIED NEW SPECIES FROM ECUADOR
}

\author{
Mark Wilson ${ }^{1,9}$, Luis E. Baquero R. ${ }^{2,3,4}$, Wiel Driessen $^{5}$, Katharine Dupree $^{1}$, \\ Karen Gil ${ }^{6}$, José Portilla ${ }^{7} \&$ Marcos Salas Guerrero ${ }^{8}$
}

\author{
${ }^{1}$ Department of Organismal Biology and Ecology, Colorado College, Colorado Springs, CO 80903, U.S.A. \\ ${ }^{2}$ Carrera de Ingeniería Agroindustrial y Alimentos, Facultad de Ingeniería y Ciencias \\ Agropecuarias. Universidad de Las Américas, Pichincha, Ecuador \\ ${ }^{3}$ Jardín Botánico de Quito, Ecuador \\ ${ }^{4}$ Instituto Nacional de Biodiversidad, Quito, Ecuador \\ ${ }^{5}$ Loosteeg 7, Panningen, The Netherlands \\ ${ }^{6}$ Universidad de Costa Rica, San José, Costa Rica \\ ${ }^{7}$ Ecuagenera, Km. 2 1/1 Vía a Cuenca Sector Llampasay, Gualaceo, Ecuador \\ ${ }^{8}$ Nature and Culture International, Chachapoyas, Peru \\ ${ }^{9}$ Author for correspondence: email: mwilson@coloradocollege.edu
}

\begin{abstract}
Pleurothallis trimeroglossa has long been considered a synonym of $P$. talpinaria. In this study we reviewed types, descriptions, drawings, paintings and living material for both names and concluded that $P$. talpinaria and P. trimeroglossa should be recognized as distinct species. An anatomical structure important in the distinction between the two is the large dome-shaped callus at the base of the lip in P. trimeroglossa. The approximate distributions and elevational ranges of the two species are discussed. During the study we recognized a novel species, described here as Pleurothallis jostii. Labellar morphology of all three species was examined. We speculate on the pollination mechanism of this group of species based on the observations of labellar micro-morphology.
\end{abstract}

KEY wORDS: labellar morphology, Pleurothallidinae, Pleurothallis, pollination, SEM, Talpinaria

Introduction. Talpinaria bivalvis H.Karst. was described by the German botanist Gustav Karl Wilhelm Hermann Karsten (Karsten 1859). The species was reported to occur in the vicinity of Bogotá, Colombia and Caracas, Venezuela in the northern Cordillera Oriental of the Andes. The holotype of T. bivalvis is currently housed in the Herbarium of the Vienna Natural History Museum (W 0075479) (Fig. 1) and an isotype is located in the Harvard University Herbarium (AMES 00287011). The original publication included both very detailed drawings and a painting (Fig. 2). This was not, however, the first recorded observation of the species, since a painting of the species by Vicente Sanchez (Fig. 3) appears among the plants illustrated during the Royal Botanical Expedition to New Granada headed by priest and botanist José Celestino Mutis. More recently the species was illustrated by Schneider (1958) in an article on Colombian orchids;
Dunsterville (Fig. 4) in Venezuelan Orchids Illustrated (Dunsterville \& Garay 1961); and by Foldats in Flora de Venezuela (Foldats 1970). In all these illustrations (Figs. 2-4), the morphology of the flower, especially that of the labellum, is consistent and clear, leaving no doubt that all of these collections and illustrations are of the same species. The name for the species, however, did not remain as T. bivalvis since Reichenbach (1886) transferred it to the genus Pleurothallis R.Br., as $P$. talpinaria Rchb.f., the name P. bivalvis Lindl. already being occupied.

In 1921 Schlechter described a similar species, Pleurothallis trimeroglossa Schltr., from a plant collected by Weberbauer near Huancayo, Junín, Peru (Schlechter 1921). He did not compare this species to the previously described $P$. talpinaria and the subsequent drawing (Schlechter 1929) did not help to clarify whether $P$. trimeroglossa was distinct 


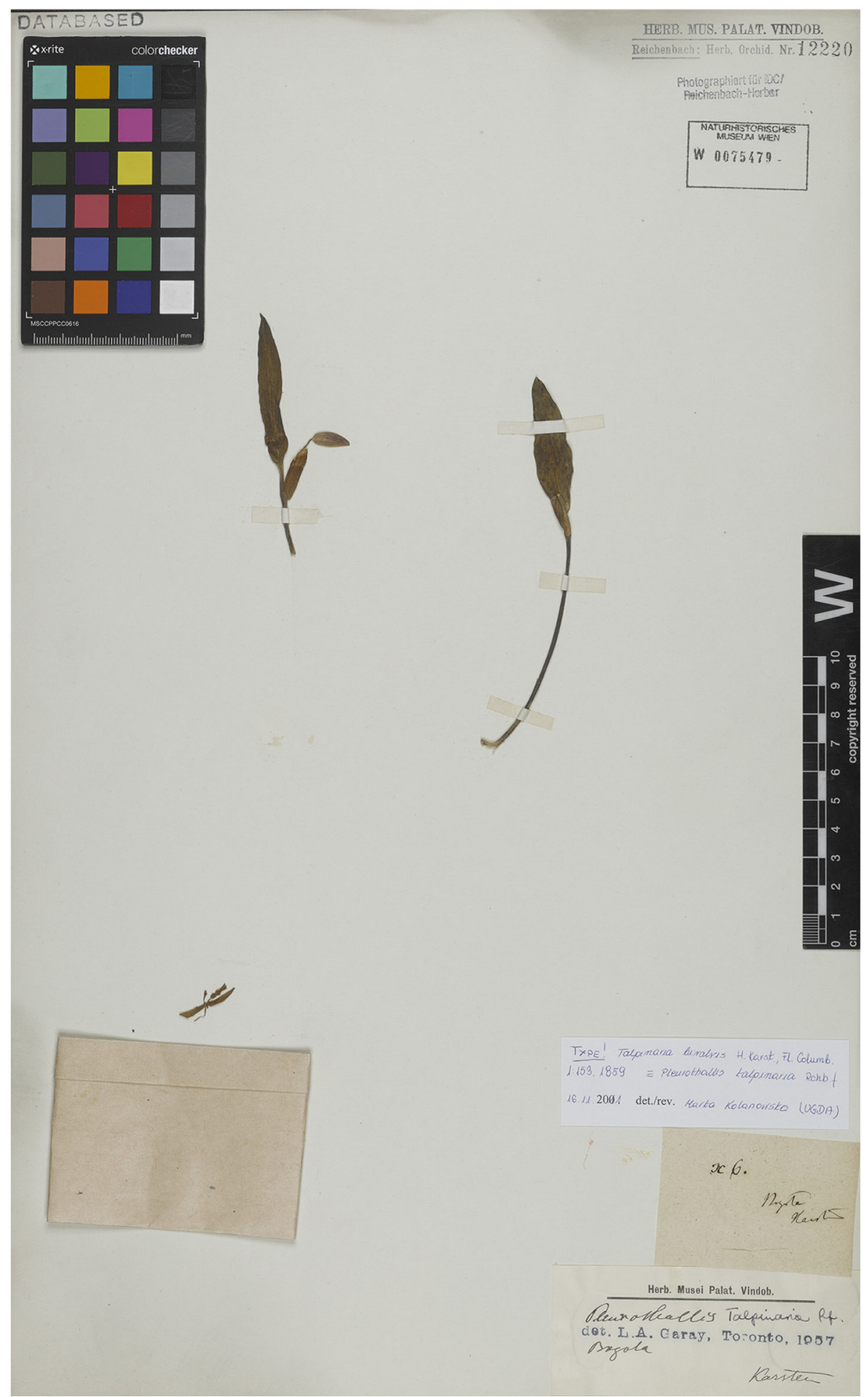

FIGURE 1. Type of Talpinaria bivalvis. Courtesy of the herbarium of the Vienna Natural History Museum, Austria (W). LANKESTERIANA 17(2). 2017. C) Universidad de Costa Rica, 2017. 


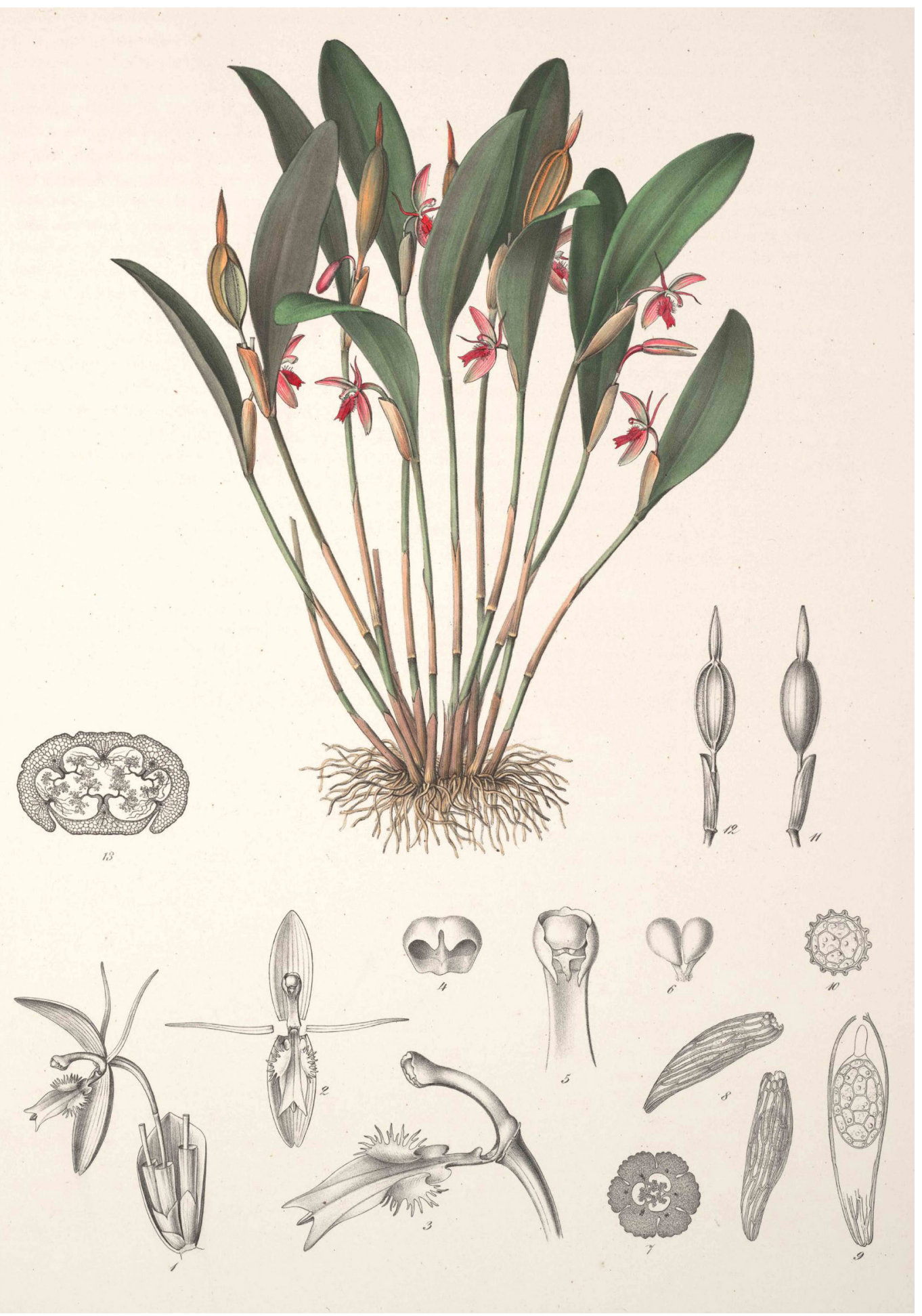

FIGURE 2. Painting of Pleurothallis talpinaria (as Talpinaria bivalvis). Painting by Gustav Karl Wilhelm Hermann Karsten. From Karsten (1859). 

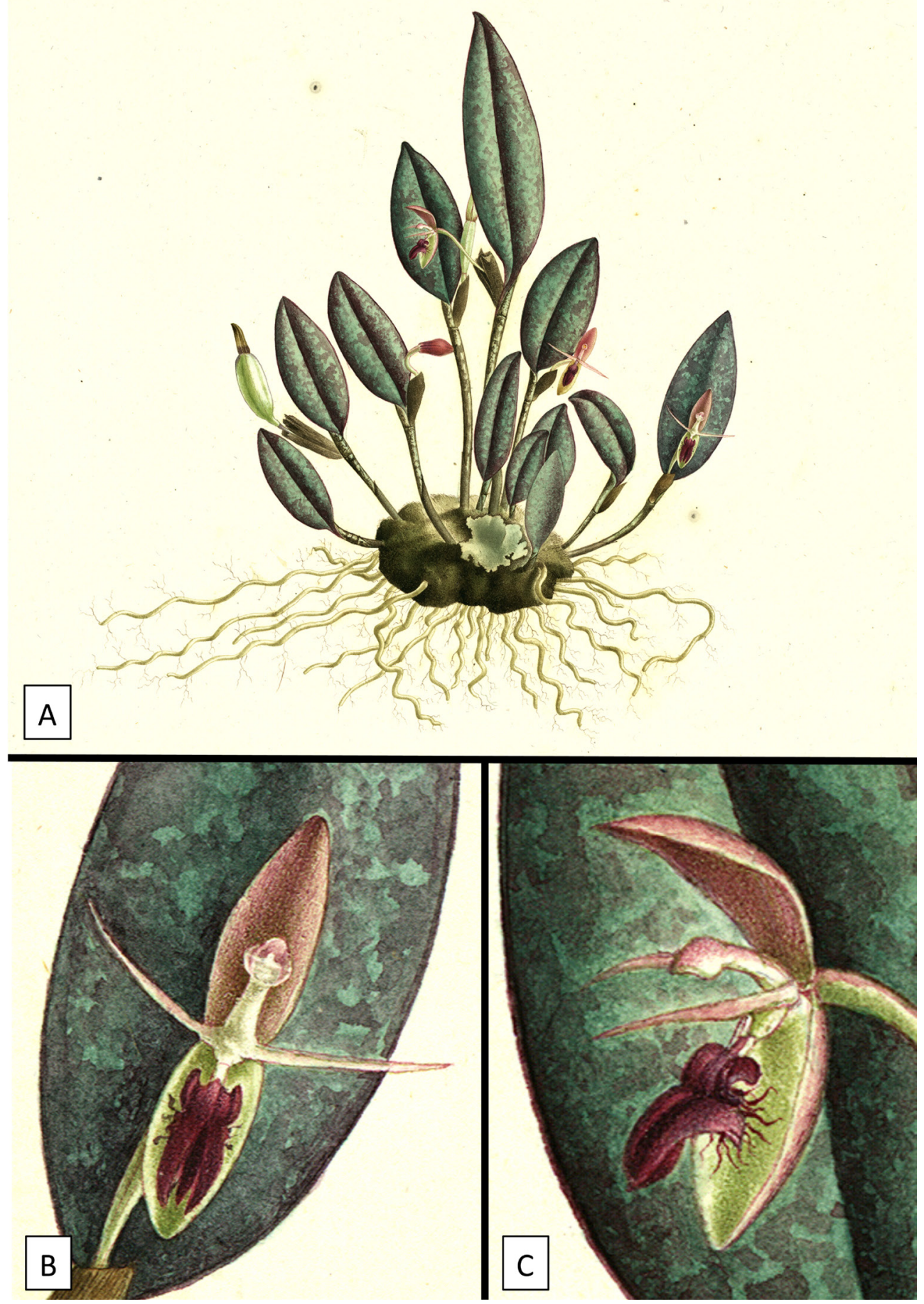

FiguRe 3. Painting of Pleurothallis talpinaria (as Rodriguezia). Painting by Vicente Sanchez. A. Whole plant. B. Flower

(front view). C. Flower (3/4 view). (Courtesy of Royal Botanical Garden of Madrid, Spain. Proyecto de digitalización de los dibujos de la Real Expedición Botánica del Nuevo Reino de Granada (1783-1816), dirigida por José Celestino Mutis: http://www.rjb.csic.es/icones/mutis Real Jardín Botánico-CSIC.) 


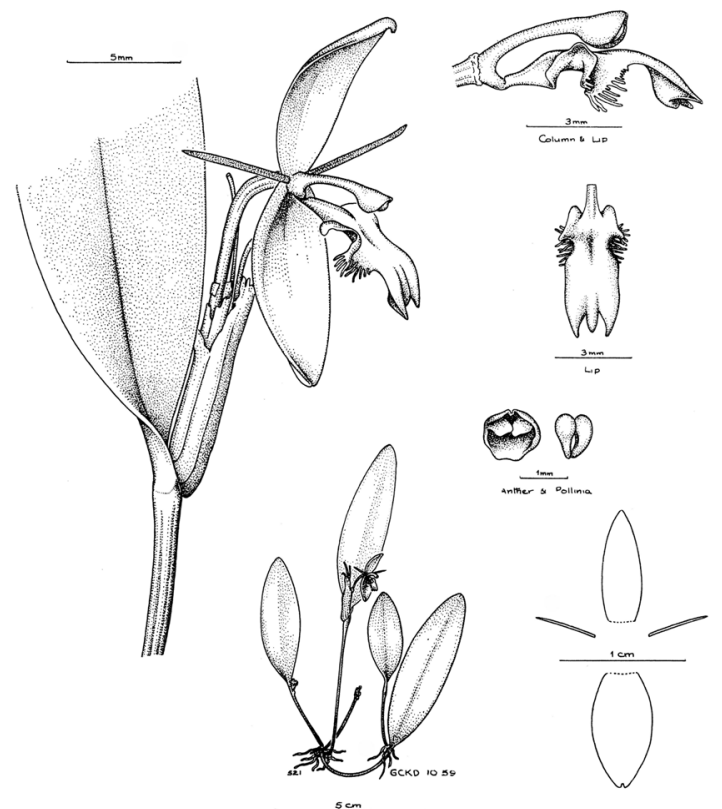

Figure 4. Drawing of Pleurothallis talpinaria. Drawn by G.

C. K. Dunsterville. From Dunsterville \& Garay (1961).

from $P$. talpinaria. Unfortunately, the holotype of $P$. trimeroglossa is believed to have been destroyed in Berlin during WWII (Luer 1998). Luckily, however, prior to its destruction, in February 1942, Gordon Dillon drew the lip and column of the type in great detail (Fig. 5) and this drawing is attached to a sheet in the Harvard University Herbarium (AMES 00074793). More recently, a lectotype was designated from Weberbauer's collection 6541 and this is currently housed in the herbarium of the Universidad Nacional Mayor de San Marcos, Lima, Peru (Luer 1998) (Fig. 6). While Schlechter $(1921,1929)$ did not compare $P$. trimeroglossa with $P$. talpinaria, perhaps because he was unaware of the latter, Schweinfurth (1942) compared the two species and concluded they were one and the same. Following Schweinfurth's lead, Luer (1998) listed P. trimeroglossa as a synonym of $P$. talpinaria and illustrated an Ecuadorian specimen presumed to be the latter species (Fig. 7).

Luer (1986), in his reorganization of the genus Pleurothallis, created subgenus Talpinaria, specifying $P$. talpinaria as the type. At the time, he added $P$. hitchcockii Ames, $P$. punctulata Rolfe and $P$. sandemanii Luer to the subgenus, though he admitted that "the flowers of subgenus Talpinaria

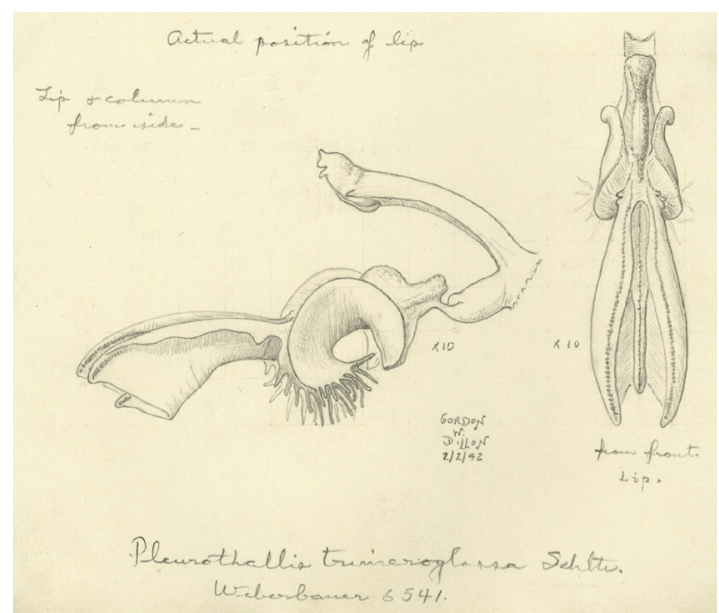

Figure 5. Drawing of Pleurothallis trimeroglossa. Prepared from the holotype by Gordon W. Dillon 2/2/1942. Courtesy of Harvard University Herbarium.

differ significantly from each other, causing an uneasy alliance" (Luer 1998). Nevertheless, despite the lack of significant morphological similarities, Luer (2004) reinstated the genus Talpinaria for the four species T. bivalvis, T. hitchcockii (Ames) Luer, T. punctulata (Rolfe) Luer and T. sandemanii (Luer) Luer.

Pridgeon, Solano and Chase (2001) included $P$. talpinaria in their molecular phylogenetic study of subtribe Pleurothallidinae. In their phylogenetic tree of the nuclear internal transcribed spacer (nrITS) sequences, $P$. talpinaria clustered in a clade with $P$. ruscifolia (Jacq.) R.Br., supporting Reichenbach's transfer of T. bivalvis to Pleurothallis. More recently, Pridgeon, Cribb, Chase and Rasmussen (2005) in Genera Orchidacearum IV included subgenus Talpinaria in their circumscription of genus Pleurothallis. Subsequent phylogenetic studies by Wilson and coworkers (2011, 2013) and Wilson (unpubl. data) have supported the inclusion of the species of this group within Pleurothallis. However, the inclusion of the aforementioned species from subgenus Talpinaria, including $P$. hitchcockii, $P$. punctulata, $P$. sandemanii, $P$. talpinaria and $P$. trimeroglossa, plus $P$. ringens C.Schweinf., clearly indicate that the subgenus is polyphyletic (Wilson unpubl. data). These observations confirm the "uneasy alliance" comment by Luer (1998) about the subgenus. For this reason, neither genus Talpinaria nor subgenus Talpinaria are employed further in this paper.

LANKESTERIANA 17(2). 2017. (C) Universidad de Costa Rica, 2017. 


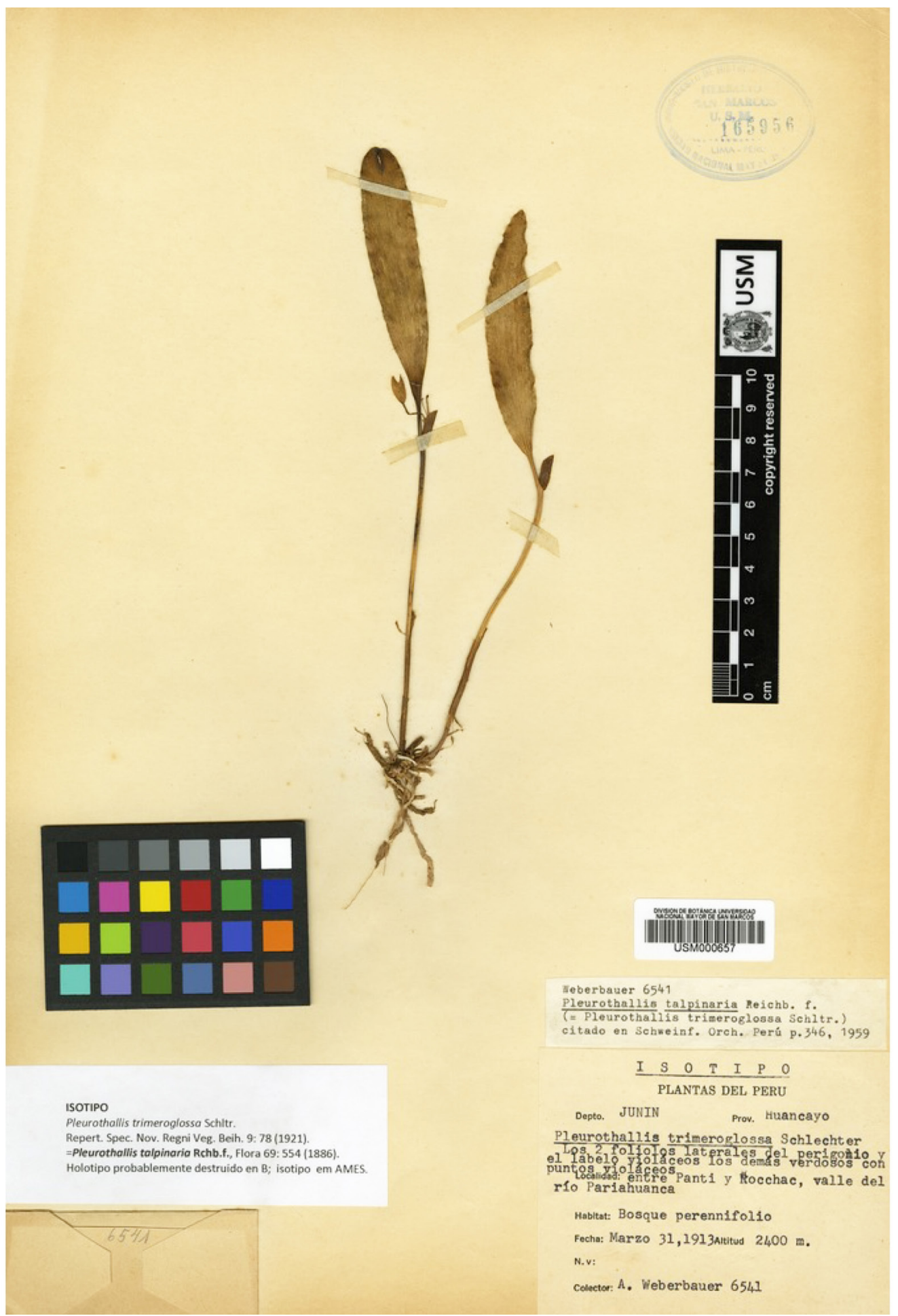

FiguRE 6. Lectotype of Pleurothallis trimeroglossa. (Courtesy of the herbarium of the Universidad Nacional Mayor de San Marcos, Peru [USM]). 


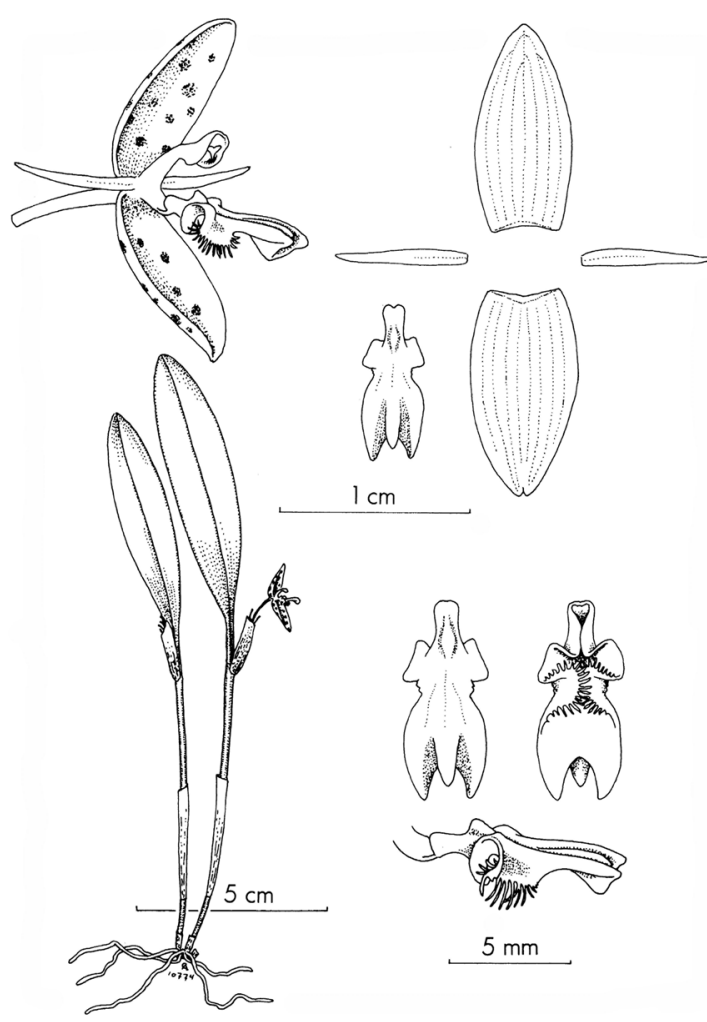

FIgure 7. Drawing of Pleurothallis trimeroglossa (as Pleurothallis talpinaria). From Luer (1998). (Courtesy of Missouri Botanical Garden Press.)

Relatively little is known about pollination in Pleurothallis sensu Pridgeon et al. (2005), but the few studies available suggest that Pleurothallis species are pollinated predominantly by Diptera and occasionally by Hymenoptera and Coleoptera (Archila \& Chiron 2015, Calderón-Sáenz 2011, Duque 1993, Duque-Buitrago et al. 2014). These scant field observations are being supplemented by micro-morphological studies of the labellum using scanning electron microscopy (SEM), which can be used to hypothesize putative pollination mechanisms for future field testing. While a preliminary study of labellar morphology of species in Pleurothallis subsection Macrophyllae-Fasciculatae (Wilson et al. 2016) has been published, this represents the first study of the labellar morphology in the P. talpinaria group.

In this manuscript we clarify the distinction between the species P. talpinaria and P. trimeroglossa and remove the second from synonymy with the first; we describe a new species from Ecuador allied to these two species; and we discuss labellar morphology in relation to possible pollination mechanisms of these three species.

\section{Materials and Methods}

Plant material- Living material of each of the three species was examined by the first author in the collections of Ecuagenera, Gualaceo, Ecuador and Mundiflora, Cuenca, Ecuador. Plants in the collection of Ecuagenera are maintained under the project "Rescate, conservación, reproducción y manejo ex-situ de la flora del Ecuador", authorized by the Ministerio del Ambiente (No 004-2016-IC-FLO-DNB/MA). Photographs of plants in Ecuador were taken with a Canon EOS 40D using a Canon $100 \mathrm{~mm}$ f 2.8 macrolens and extension tubes as required. These were used for creation of the Lankester composite digital plates (LCDPs). Plants were also imported into the U.S.A. from Ecuagenera and grown in the living collection at Colorado College. Material from these imported plants was used for the creation of herbarium specimens accessioned into the herbarium at Colorado College (COCO). Flowers were preserved in Kew Mix (5\% formalin $[37.6 \%$ formaldehyde], $53 \%$ methanol, $5 \%$ glycerol, $37 \%$ deionized water).

Morphological and taxonomic comparisons - Flowers of P. talpinaria and P. trimeroglossa were compared in detail to establish that these are two distinct species. Flowers of $P$. talpinaria and P. trimeroglossa were then compared to flowers of the putative new species, labeled P. talpinaria "purple" in the collection of Ecuagenera, to determine its novelty. To confirm that the species had not been described elsewhere, the new species was compared to descriptions in all pertinent literature, including but not limited to: Bennet and Christenson (1993), Dodson (2003), Dodson and Dodson (1980, 1982), Luer (1975a, 1975b, 1975c, 1976, 1977, 2009, 2011), Luer and Thoerle (2013) and Schweinfurth $(1959,1970)$. The labella of $P$. talpinaria, $P$. trimeroglossa and the new species were compared in detail by stereo-microscopy, macro-photography and SEM. Flowers for SEM were prepared as described previously (Wilson et al. 2016).

DNA sequence comparisons - . The nrITS region was sequenced for P. trimeroglossa and the new species using methods described previously (Wilson et al. 2017).

LANKESTERIANA 17(2). 2017. (C) Universidad de Costa Rica, 2017. 


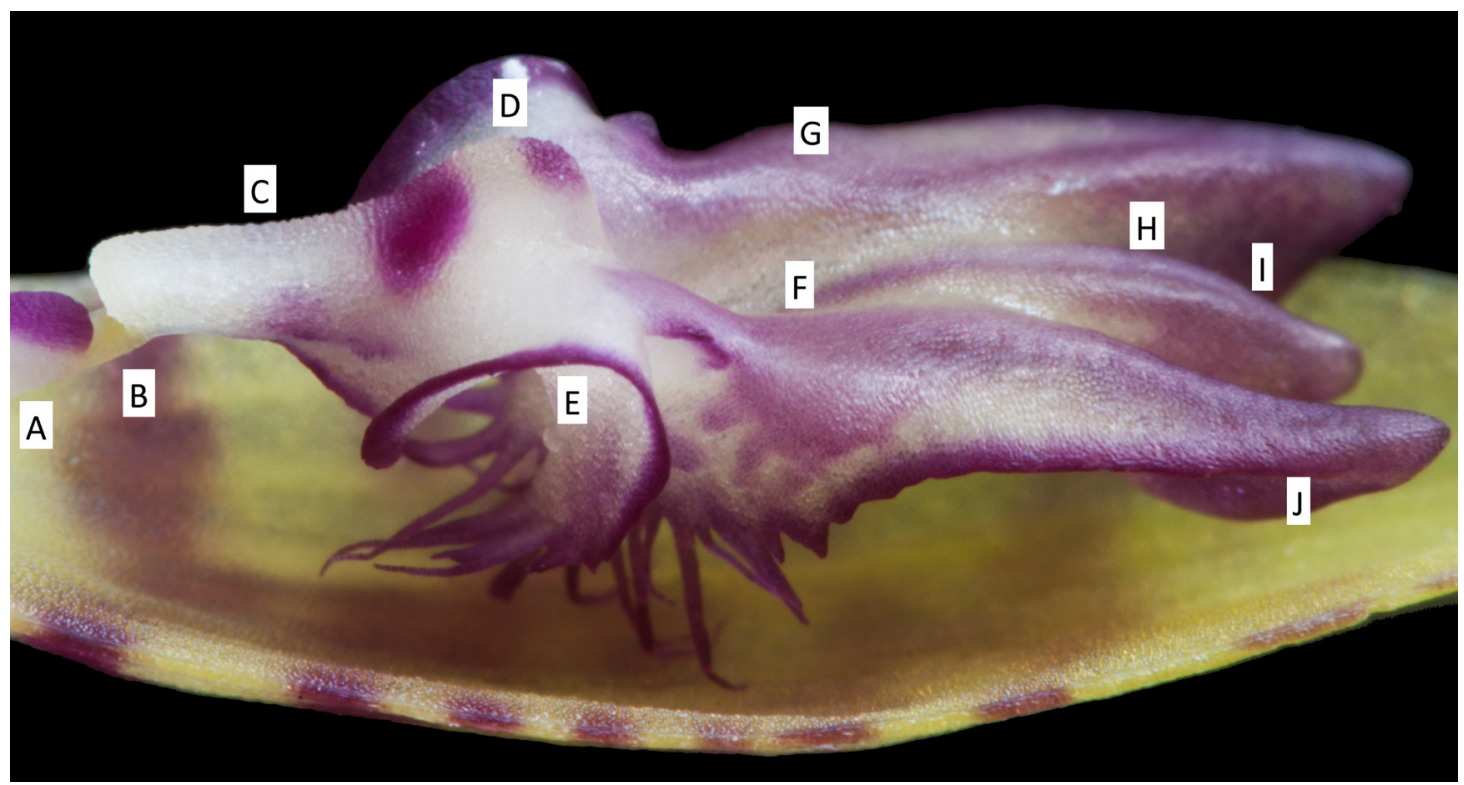

Figure 8. Labellum of Pleurothallis trimeroglossa. A. Column foot; B. Strap-like attachment; C. Hypochile; D. Callus; E. Auriculate basal lobe; F. Sulcus; G. Mesochile; H. Epichile. I. Central lobe; J. Lateral lobe. Prepared by Mark Wilson.

\section{Results}

Morphological and taxonomic comparisons-. Specimens of $P$. talpinaria (M. Wilson \& J. Portilla PL0946 COCO); P. trimeroglossa (M. Wilson \& J. Portilla PL0600 and PL0947 COCO; M. Salas Guerrero 129 USM); and the new species of Pleurothallis (M. Wilson \& J. Portilla PL0314, PL0517 and PL0782 COCO; and PL0974 HA), were examined by macrophotography, stereo-microscopy and SEM.

The labella of $P$. talpinaria and $P$. trimeroglossa are similar consisting of a protuberant, 5-lobed structure. The terete hypochile of the labellum is attached to the column foot via a flexible strap which presumably permits labellar motility; above the hypochile are two auriculate, revolute, highly fimbriate basal lobes; the mesochile exhibits a distinct sulcus; and the epichile consists of three acute, ridge-like lobes (Fig. 8). The labellum of $P$. trimeroglossa can be distinguished from that of $P$. talpinaria by the presence of a very distinct callus in the shape of a laterally compressed dome (Figs. 8-9), as well as being significantly shorter and narrower (Table 1). The labellum of the new species possesses the same overall architecture as that of $P$. talpinaria and $P$. trimeroglossa, but it is most similar to that of P. talpinaria, in that it also lacks the domed callus on the hypochile. In comparison to the labellum of $P$. talpinaria it is significantly shorter and narrower; the terete hypochile is much shorter; the sulcus is less pronounced; and the keel of the central apical lobe is shallower (Figs. 9-10).

TABLE 1. Comparison of dimensions of Pleurothallis talpinaria, Pleurothallis trimeroglossa and Pleurothallis jostii.

\begin{tabular}{l|l|l|l}
\hline & $\begin{array}{l}\text { Pleurothallis } \\
\text { talpinaria }\end{array}$ & $\begin{array}{l}\text { Pleurothallis } \\
\text { trimeroglossa }\end{array}$ & $\begin{array}{l}\text { Pleurothallis } \\
\text { jostii }\end{array}$ \\
\hline Whole flower $(\mathrm{mm})$ & $23-27 \times 23-24$ & $22-24 \times 14-15$ & $16-19 \times 10-14$ \\
\hline Dorsal sepal $(\mathrm{mm})$ & $12.8-14 \times 5-5.4$ & $10.5-11.3 \times 3.4-4$ & $10-10.5 \times 5.5-6.7$ \\
\hline Synsepal $(\mathrm{mm})$ & $12.5-13 \times 5.3-6$ & $10.5-11.7 \times 4.5-4.8$ & $10 \times 6-6.8$ \\
\hline Petals $(\mathrm{mm})$ & $11-12 \times 1.0$ & $5.7-6.0 \times 0.6$ & $6-7 \times 1-1.4$ \\
\hline Column length $(\mathrm{mm})$ & 6.8 & 6.0 & $4.6-4.8$ \\
\hline Labellum $(\mathrm{mm})$ & $11 \times 4-4.2$ & $7.7-8.5 \times 2.8-3$ & $7.5-8 \times 3.3-3.9$ \\
\hline Callus on labellum & No & Yes & No \\
\hline
\end{tabular}




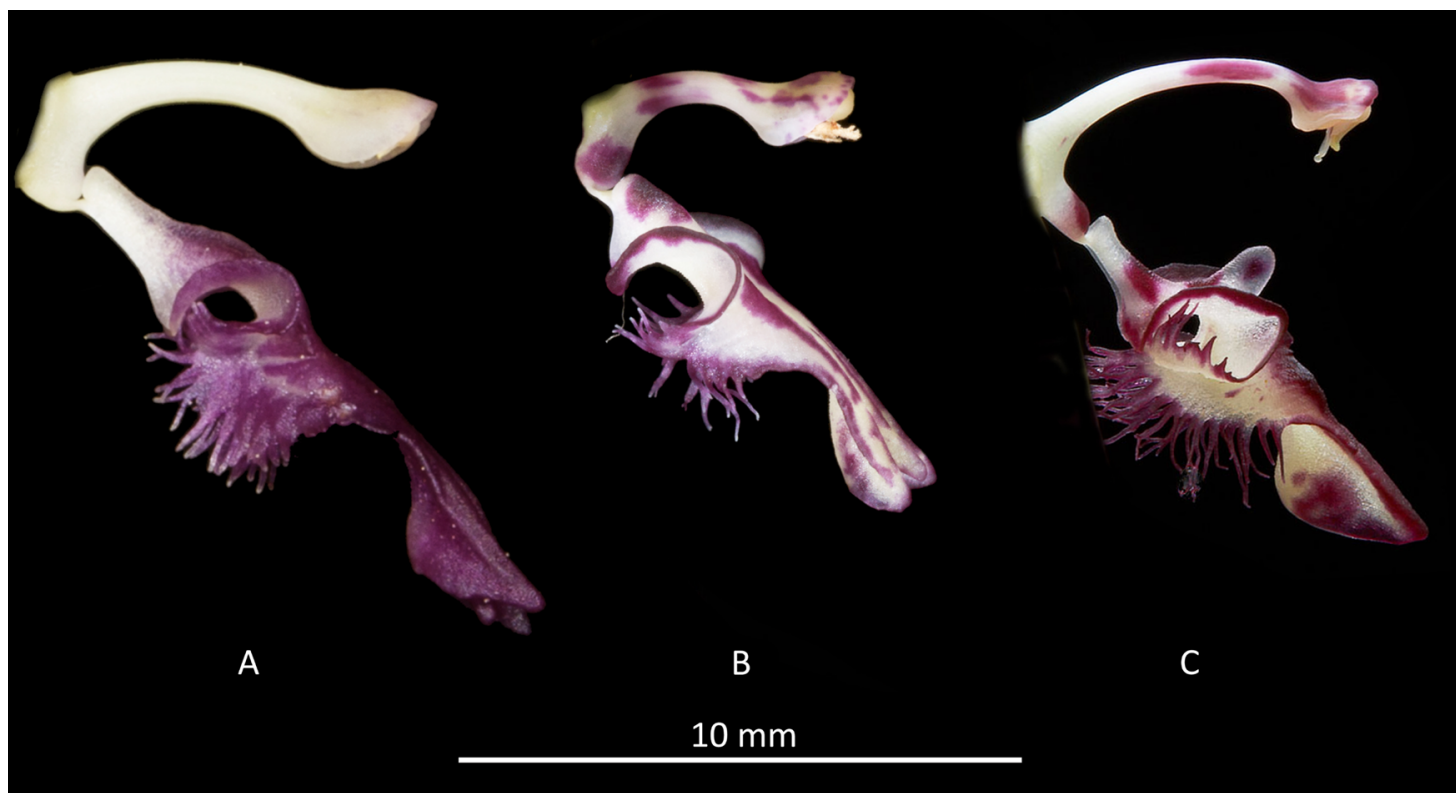

Figure 9. Column and labella. A. Pleurothallis talpinaria (photo by Wilson); B. Pleurothallis jostii (photo by Eric Hunt); C. Pleurothallis trimeroglossa (photo by Dale Borders).

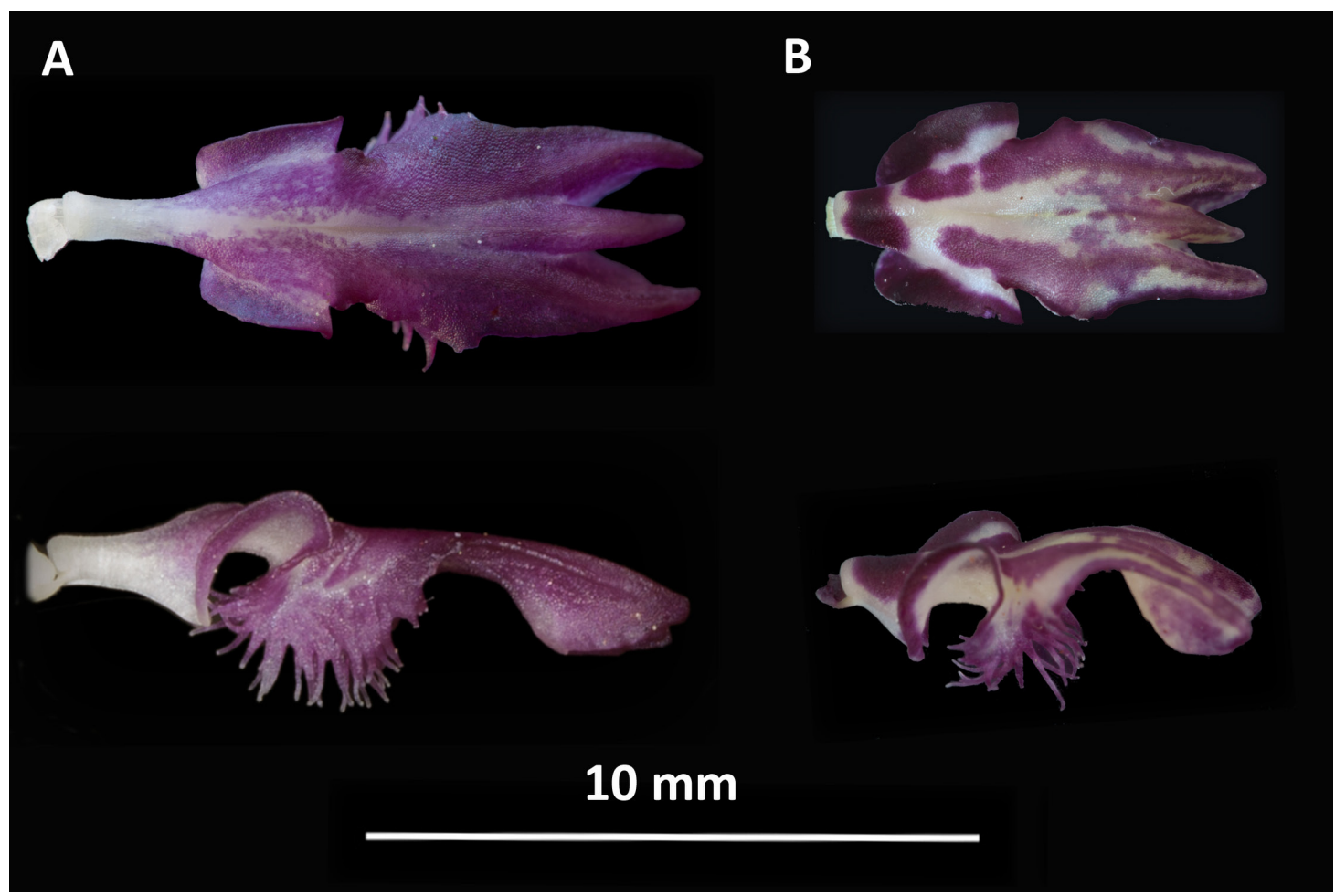

Figure 10. Labella of Pleurothallis talpinaria (A) and Pleurothallis jostii; (B). Prepared by Mark Wilson.

When the labellum of the new species was examined by SEM, no morphology characteristic of secretory tissues found in other Pleurothallidinae were observed on the adaxial surface (Fig. 11). 


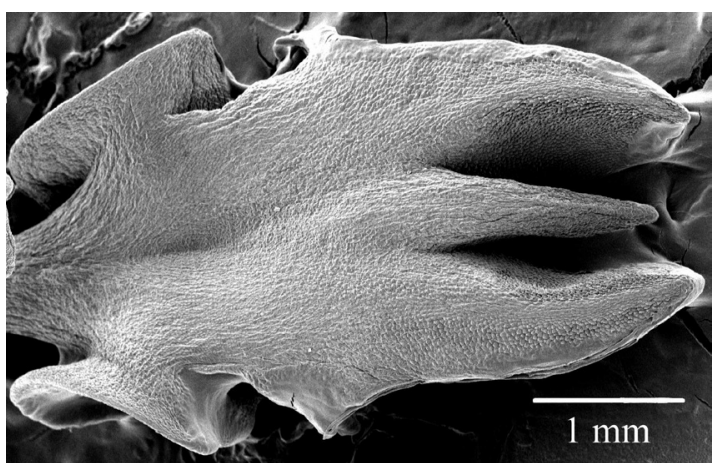

FIGURE 11. Scanning electron micrograph of labellum of Pleurothallis jostii Electron micrograph by Katharine Dupree.

The columns of $P$. talpinaria and $P$. trimeroglossa are similar consisting of a slender, terete, arching structure, with a pronounced column foot at the base and a hood surrounding the clinandrium at the apex (Fig. 9). The column of P. trimeroglossa, however, is significantly narrower and more arching; the column foot is longer and more pronounced; and the transition from terete column to hood of the clinandrium is more abrupt (Fig. 9). The column of the new species is shorter and more stout than either of the other species, with the least pronounced column foot (Fig. 9).

In color, $P$. talpinaria is very consistent, with pale cream sepals, petals and column and a pale purple labellum with a white hypochile (Figs. 12-13). P. trimeroglossa, on the other hand, exhibits significant color variations (Fig. 14).

DNA sequence comparisons- The nuclear ITS sequences for P. talpinaria (GenBank AF262840), P. trimeroglossa PL0600 and the new species PL0517 were identical (Wilson et al., unpubl. data). These sequences will be uploaded to GenBank at a later date as part of the ongoing Pleurothallis phylogeny project.

\section{Discussion}

Pleurothallis talpinaria and P. trimeroglossa have been considered to represent a single species since Schweinfurth (1942) examined Peruvian specimens of $P$. trimeroglossa. This taxonomic opinion was followed by Luer $(1998,2004)$ and has not been challenged until this time. We, however, believe that these are two distinct species, different both in floral morphology and distribution. Indeed, even
Schweinfurth (1942) commented on the differences between the type specimen of Peruvian P. trimeroglossa and the description of $P$. talpinaria before erroneously concluding they were the same species. For example: "The flowers are slightly smaller than those described in $\mathrm{T}$. bivalvis, while the petals are markedly shorter than the sepals and not almost equalling them as in $\mathrm{T}$. bivalvis."

All the depictions of $P$. talpinaria, from the original drawings and paintings of Karsten (1859, Fig. 2) and Sanchez (date unknown, Fig. 3), to that of Schneider (1958) and that of Dunsterville (in Dunsterville \& Garay 1961, Fig. 4) show specimens that are consistent in both morphology with the flowers attached to the holotype and isotype. Specimens observed in situ in Cundinamarca, Colombia (Fig. 13) and in collections (Fig. 12) are identical with these earlier drawings and paintings. This species always has cream sepals and petals and a pale pink-purple lip (Figs. 12-13) and, most importantly, never has a domed callus at the base of the lip (Figs. 9, 10A). In contrast, $P$. trimeroglossa has a very distinct, domed callus near the base of the lip (Figs. 5, 8, 9C). The presence of the domed callus on the hypochile of Luer's drawing of an Ecuadorian specimen identifies that plant as $P$. trimeroglossa. In addition to the morphological differences, color differences and size differences (Table 1), the species also appear to have differing distributions. Because of these differences, we propose that the two species, $P$. talpinaria and $P$. trimeroglossa are distinct and they are removed from synonymy herein.

The new species described herein (Figs. 9B, 10B, $11,15-17)$ is distinct morphologically and in size (Table 1) from both $P$. talpinaria and $P$. trimeroglossa. Like $P$. talpinaria it lacks a callus at the base of the lip (Figs. 10B, 11), but it should not be confused with that species because of the marked differences in size (Table 1). In coloration it is more similar to some variants of P. trimeroglossa, but it should not be confused with that species due to the presence of the callus on the lip of $P$. trimeroglossa and the very marked differences in flower size (Table 1).

The nrITS region was sequenced for $P$. trimerogloss $a$ and the new species and these sequences were compared to the nrITS sequence for $P$. talpinaria obtained by Pridgeon and coworkers (2001). The 


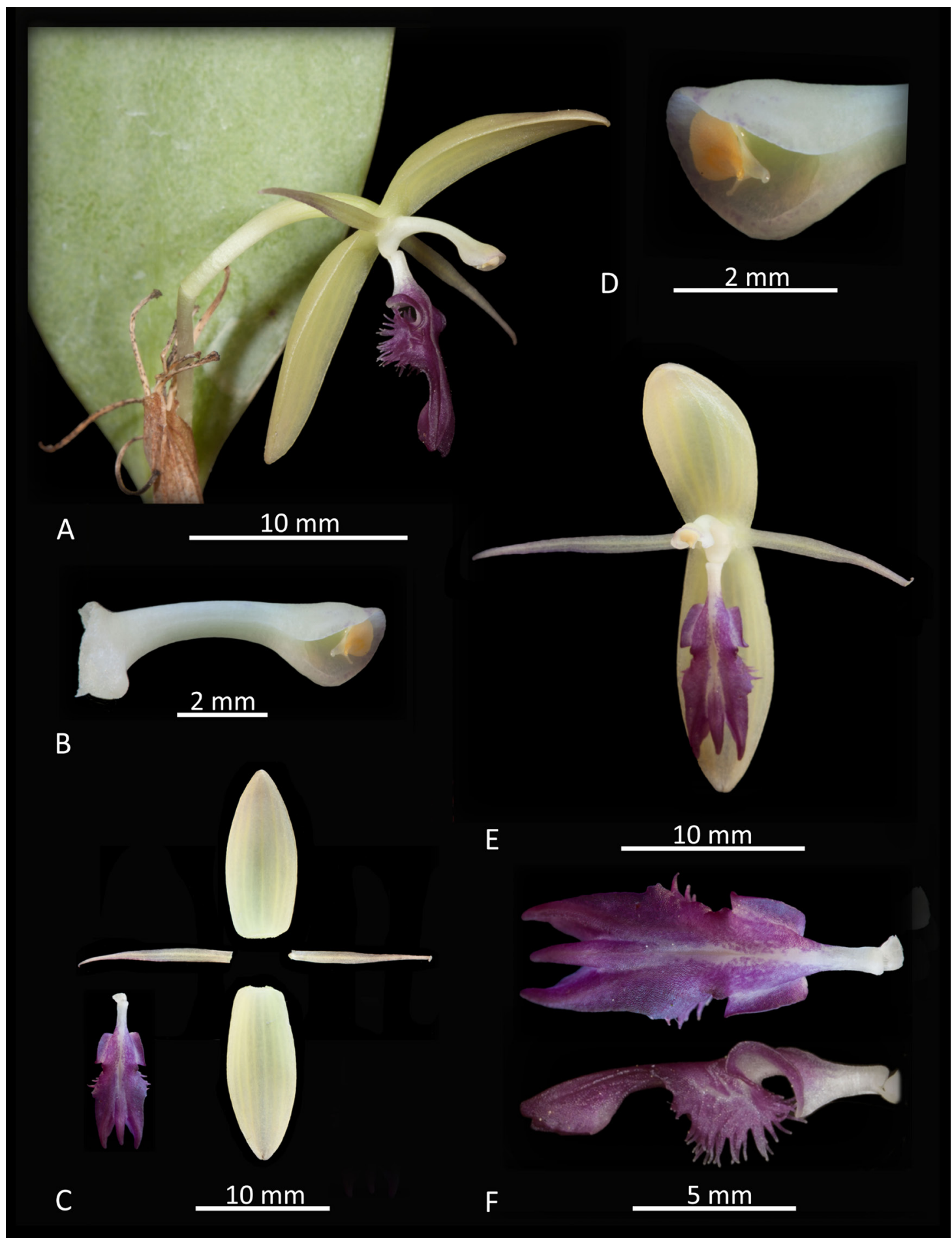

FIgURE 12. Lankester composite digital plate of Pleurothallis talpinaria. A. Whole flower, ovary, pedicel and spathaceous bract; B. Column (3/4 ventral view); C. Floral dissection; D. Column tip and anther; E. Whole flower (front view); F. Labellum (dorsal and lateral views). LCDP prepared by Mark Wilson from M. Wilson \& J. Portilla PL0946. 

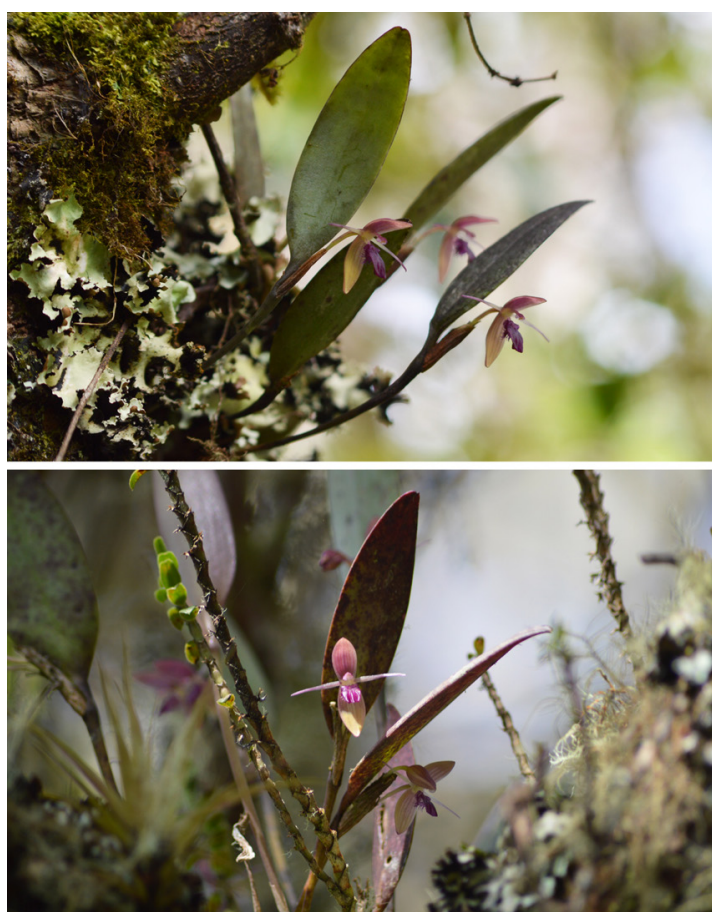

FIgURE 13. Pleurothallis talpinaria in situ in Reserva Biológica El Encenillo, Guasca, Cundinamarca, Colombia. Photographs by Karen Gil.

nrITS sequences were invariant and not useful for discriminating among the three species. This situation is not at all uncommon in the species-rich genus Pleurothallis (Wilson et al. unpubl. data) and does not imply that P. talpinaria, P. trimeroglossa and the new species are one and the same. To find a sequence-based method of species discrimination, future sequencing will focus on the more variable regions 3' $y c f, \operatorname{trn} L-F$ and $\operatorname{trn} H-p s b A$.

Unfortunately, the distribution data for $P$. talpinaria reported by Luer (1998) and Tropicos (2017) represent the combined distributions of $P$. talpinaria and $P$. trimeroglossa. Full characterization of the geographic and elevational distributions of $P$. talpinaria and $P$. trimeroglossa will require extensive field work. Although it will be useful to examine collections in herbaria in Venezuela, Colombia, Ecuador, Peru and Bolivia, P. talpinaria and P. trimeroglossa are vegetatively indistinguishable and the majority of herbarium specimens do not have a flower on the sheet or preserved in spirit. However, we can infer approximate distributions for the two species from the information available.
The type locality for $P$. talpinaria is in the Department of Cundinamarca, Colombia. Based upon recent photos taken in situ by Colombian botanists, the species also occurs in the Departments of Caldas and Santander. We believe that the Venezuelan collections all represent this species. Therefore, tentatively, pending further examination of herbarium collections and field work, one could characterize the distribution of P. talpinaria as the Cordillera Oriental of the Andes, from central and northeastern Colombia into southwestern Venezuela. In this study, P. talpinaria was observed in situ growing epiphytically in a subparamo forest of encenillo (Weinmannia tomentosa L.f.) in the Reserva Biológica El Encenillo, Guasca, Cundinamarca, Colombia (Fig. 13).

Inferring a distribution of $P$. trimeroglossa is more challenging because less information is available. The type locality for $P$. trimeroglossa is near Huanuco, Department of Junín, Peru. However, the species was observed by author Salas growing epiphytically on the trunks of palm trees in Chachapoyas Province, in the Department of Amazonas, Peru, much closer to Ecuador. Examination of specimens from the herbarium at Selby Botanical Gardens (SEL) suggests that this species has been collected in the Ecuadorian provinces of Loja, Zamora-Chinchipe, MoronaSantiago, Pastaza and Napo, all on the eastern slope of the Andes. Pleurothallis trimeroglossa does not appear to have been collected further west than these provinces, or further north than Napo. The report of P. talpinaria in Bolivia (Jiménez-Pérez 2011), possibly represents the most southerly populations of P. trimeroglossa, but this needs to be verified. It also remains to be determined whether the color variants of P. trimeroglossa (Fig. 14) represent merely geographic variation in the species or whether there are in fact cryptic species within the concept of $P$. trimeroglossa presented here. Studies to resolve these questions are ongoing and this article represents just the first in a series on the P. talpinaria-P. trimeroglossa group.

While an accurate determination of the elevational range of these two species will require additional study, P. talpinaria appears to grow at a higher mean elevation than $P$. trimeroglossa. In Cundinamarca, Colombia, P. talpinaria occurs over an elevational range of approximately $2600-3200 \mathrm{~m}$ above sea level. 

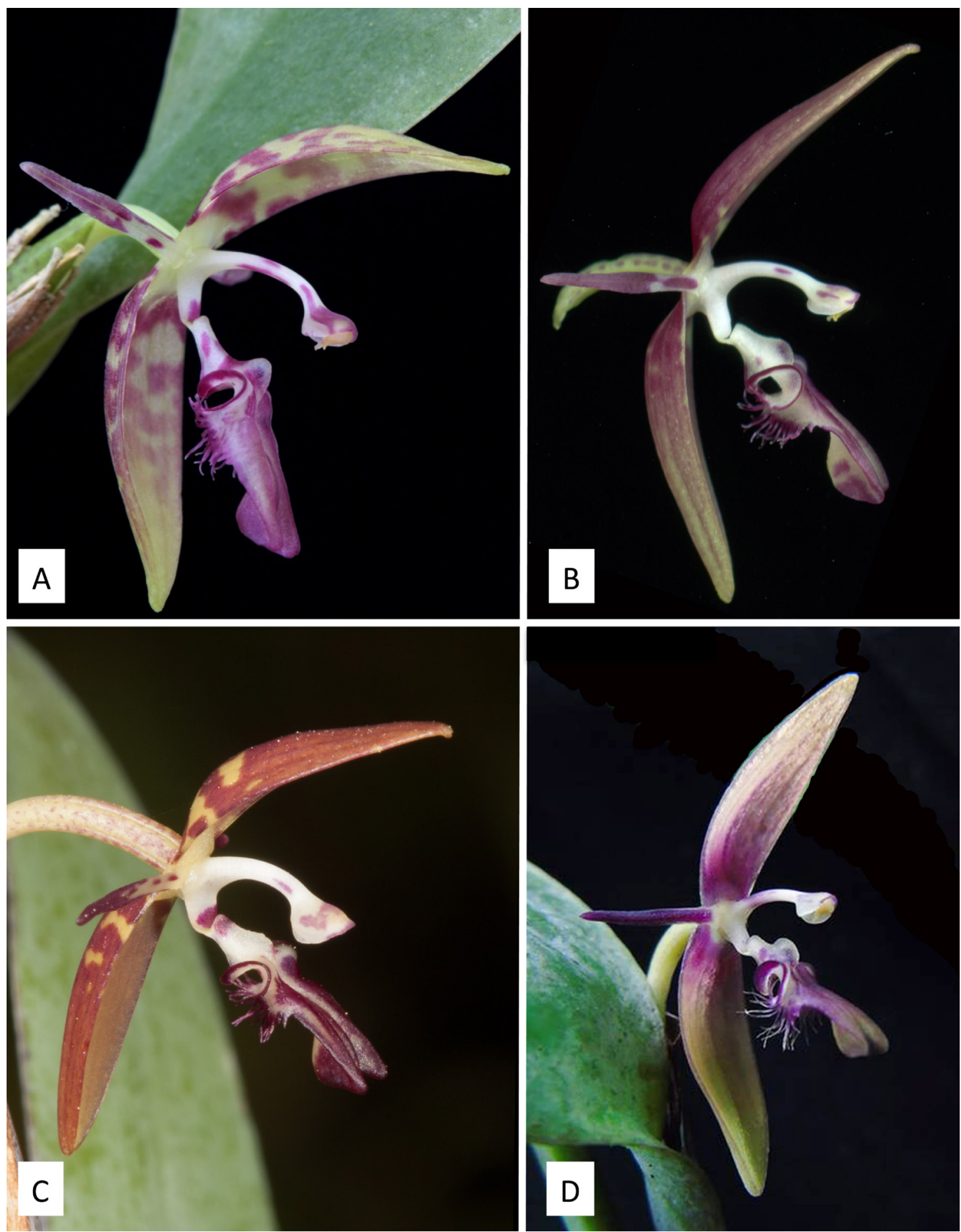

FIgURE 14. Color variation in Pleurothallis trimeroglossa. A. Ecuadorian specimen (ex situ photo by Wiel Driessen); B. Ecuadorian specimen from Ecuagenera (ex situ photo by Mark Wilson); C. Ecuadorian specimen from Mundiflora (photo by Mark Wilson); D. Peruvian specimen from Chachapoyas, Amazonas, Peru (in situ photograph by Marcos Salas Guerrero). 
P. trimeroglossa on the other hand has been recorded over the range 1780-2842 m. P. trimeroglossa has been photographed as low as $1780 \mathrm{~m}$ Rioja, San Martín, Peru (José Dilmer Edquen Oblitas, pers. comm.); the type material was collected in Huancayo, Junín, Peru at an elevation of $2400 \mathrm{~m}$; and it has been collected in Amazonas, Peru from $2680 \mathrm{~m}$ to $2842 \mathrm{~m}$ (M. Salas Guerrero 129).

Undoubtedly, the most distinctive floral feature of all three species is the highly modified, tri-lobed labellum. The auriculate, highly fimbriate basal lobes are unique in Pleurothallis, and even in Pleurothallidinae, as far as we are aware. We might assume that such a lip has evolved to attract a very specific type of pollinator. As mentioned earlier, the few field observations that have been made suggest that species in Pleurothallis sensu Pridgeon (2005) are pollinated predominantly by Diptera and secondarily by Coleoptera and Hymenoptera. In none of the observations of living plant material or numerous photographs of the three species have we ever seen any evidence of a liquid nectar-like reward. Nor did SEM indicate the presence of even a vestigial nectary or "glenion" as occurs in Pleurothallis subsections Macrophyllae-Fasciculatae (Wilson et al. 2016) and Acroniae (Wilson unpubl. data), or any other possible secretory tissue (Fig. 11). This suggests that these are rewardless flowers and that pollination involves some form of deception. The flowers seem inordinately complex for a mimic of another rewarding species, both in the extensive fimbriation and the presence of an articulation allowing free labellar motility. We hypothesize therefore that these flowers are pollinated by sexual deceit and that pollination involves pseudocopulation with a relatively large dipteran or hymenopteran pollinator. We further hypothesize that the large callus near the base of the lip in P. trimeroglossa, that is absent in P. talpinaria, serves to position a somewhat smaller pollinator against the anther. Of course, such speculation will have to be confirmed by in situ observation in the future.

\section{Taxonomic treatment}

Pleurothallis talpinaria Rchb.f., Flora 69: 554. 1886. Bas. Talpinaria bivalvis H.Karst. Fl. Columb. (H. Karst.) i. 153. t. 76 (1859).
TYPE: Colombia. Cundinamarca: Bogotá. H. Karsten 6 (holotype: W! [0075479]).

Additional material Studied: Colombia. Cundinamarca: Bogotá. H. Karsten 6 (isotype: AMES! [00287011]). Ecuador. Purchased from Ecuagenera without collection data and flowered in cultivation at Colorado College, M. Wilson \& J. Portilla PL0946 (COCO!).

Pleurothallis trimeroglossa Schltr. Repert. Spec. Nov. Regni Veg. Beih. 9: 78. 1921.

TYPE: Peru. Junín: Huancayo, collected 31 March, 1913, A. Weberbauer 6541 (lectotype: USM!).

Additional material studied: Peru. Junín: Huancayo. A. Weberbauer 6541 (isotype: AMES! [00074792]). Drawing of type (AMES! [00074793]). Peru. Chachapoyas, Amazonas. M. Salas Guerrero 129 (USM!). Ecuador. Purchased from Ecuagenera without collection data as P. talpinaria and flowered in cultivation at Colorado College and identified as $P$. trimeroglossa, M. Wilson \& J. Portilla PL0600 and PL0947 (COCO!).

Pleurothallis jostii Mark Wilson \& J.Portilla, sp. nov. (Figs. 15-17).

TYPE: Ecuador. Flowered in cultivation at Ecuagenera Orchid Nursery, Gualaceo, Ecuador as Pleurothallis talpinaria "purple", without collection data, November 2015, M. Wilson \& J. Portilla PL0974 (holotype: HA!).

Diagnosis. Pleurothallis jostii can be distinguished from P. talpinaria by the smaller flower; the color of the sepals, yellow brown heavily mottled with purplebrown vs. pale cream; the color of the petals, deep purple $v s$. pale cream; the color of the labellum, white mottled with purple $v s$. predominantly pale purple; the length of the column which is $4.6-4.8 \mathrm{~mm}$ in $P$. jostii vs. $\sim 6.8 \mathrm{~mm}$ in P. talpinaria; the shorter labellum, $7.5-8.0 \mathrm{~mm}$ long vs. $\sim 11 \mathrm{~mm}$ long; and the shorter hypochile at the articulation with the column foot in P. jostii. Pleurothallis jostii can be distinguished from $P$. trimeroglossa by the smaller flower; the petal width which is $1.0-1.4 \mathrm{~mm}$ in $P$. jostii vs. $\sim 0.6 \mathrm{~mm}$ in $P$. trimeroglossa; the absence of a domed callus on the hypochile of $P$. jostii and the presence of a distinct, 


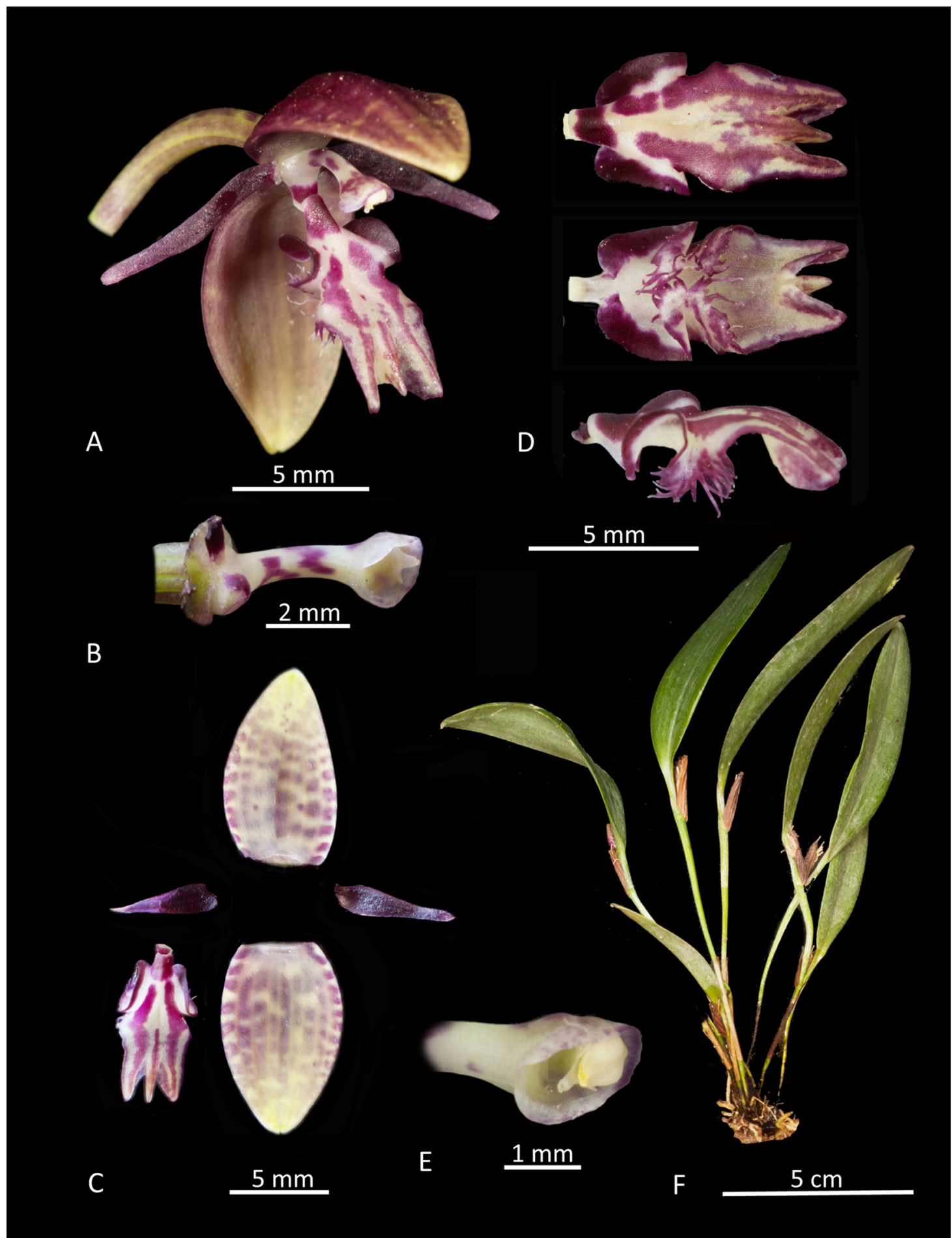

Figure 15. Lankester composite digital plate of Pleurothallis jostii. A. Whole flower (3/4 view); B. Column (3/4, ventral view); C. Floral dissection; D. Labellum (dorsal, ventral and lateral views); E. Column tip and anther; F. Whole plant. LCDP prepared by Mark Wilson from the holotype M. Wilson \& J.Portilla PL0974. 

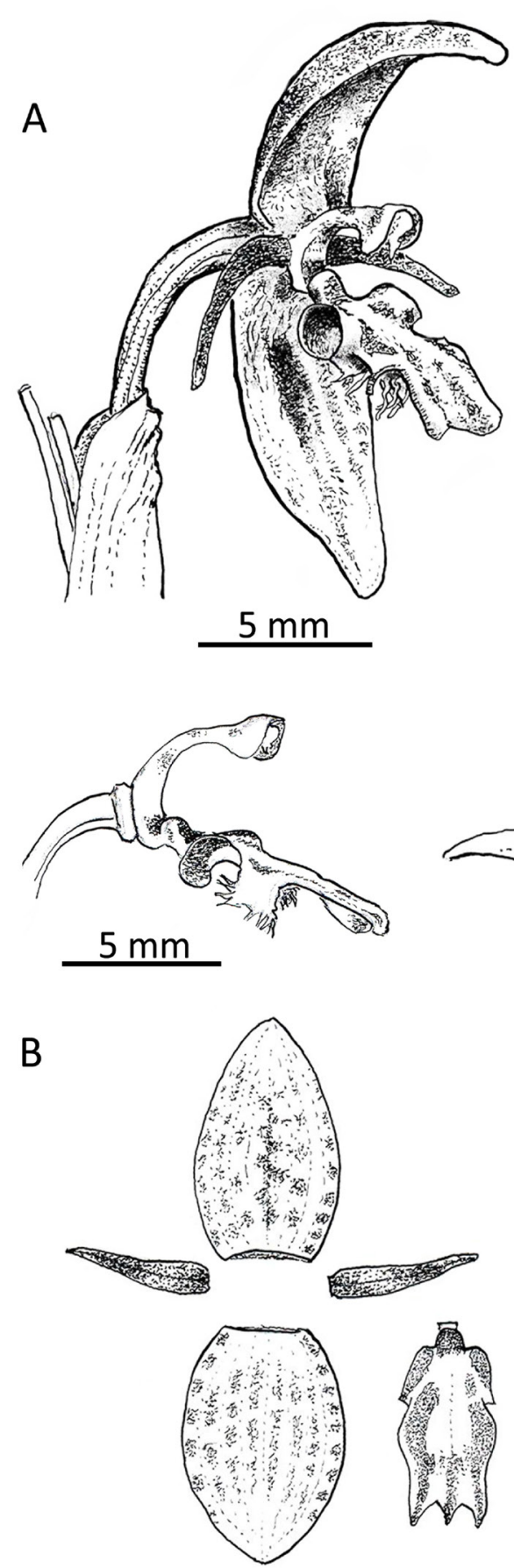

C
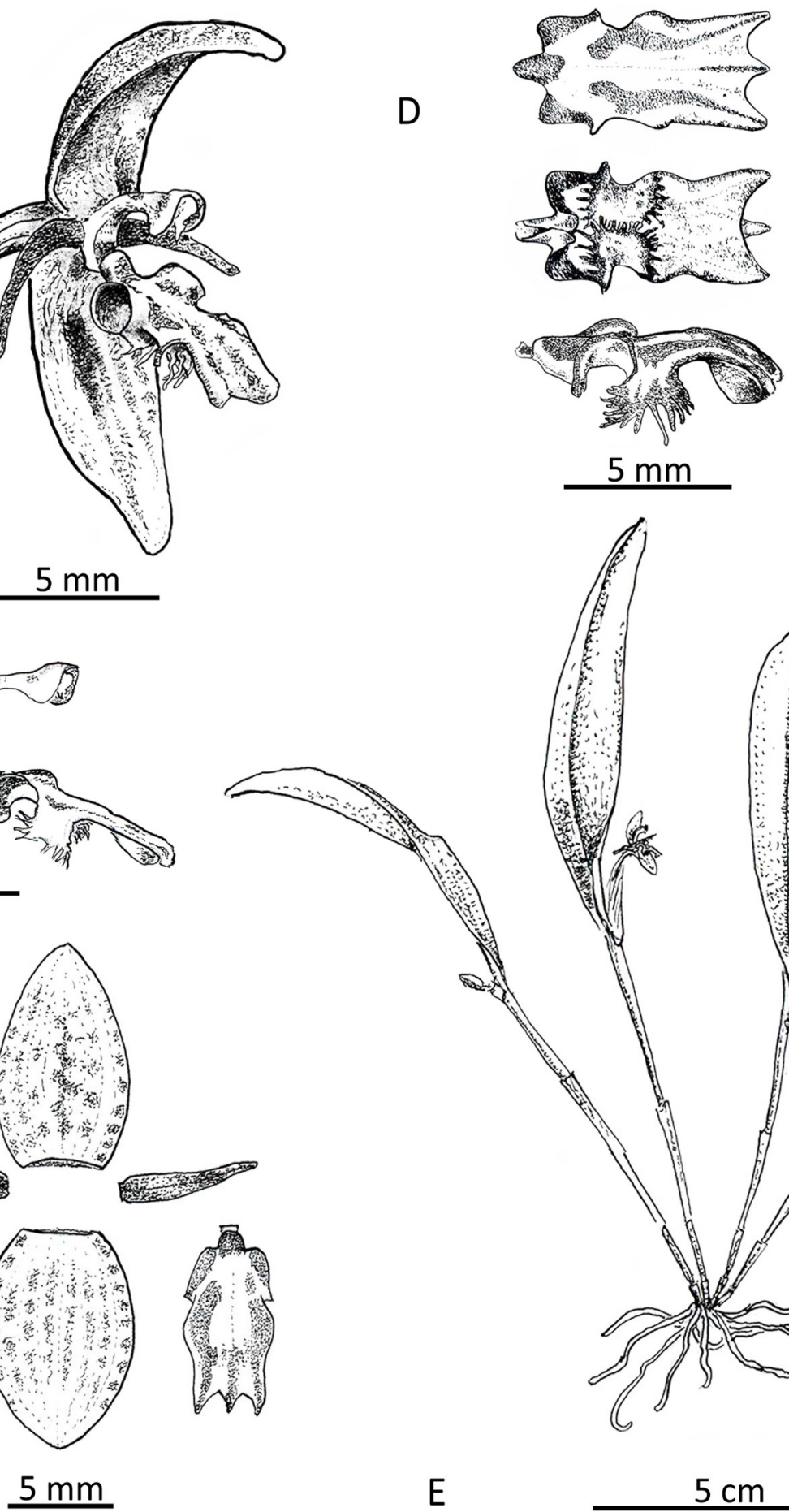


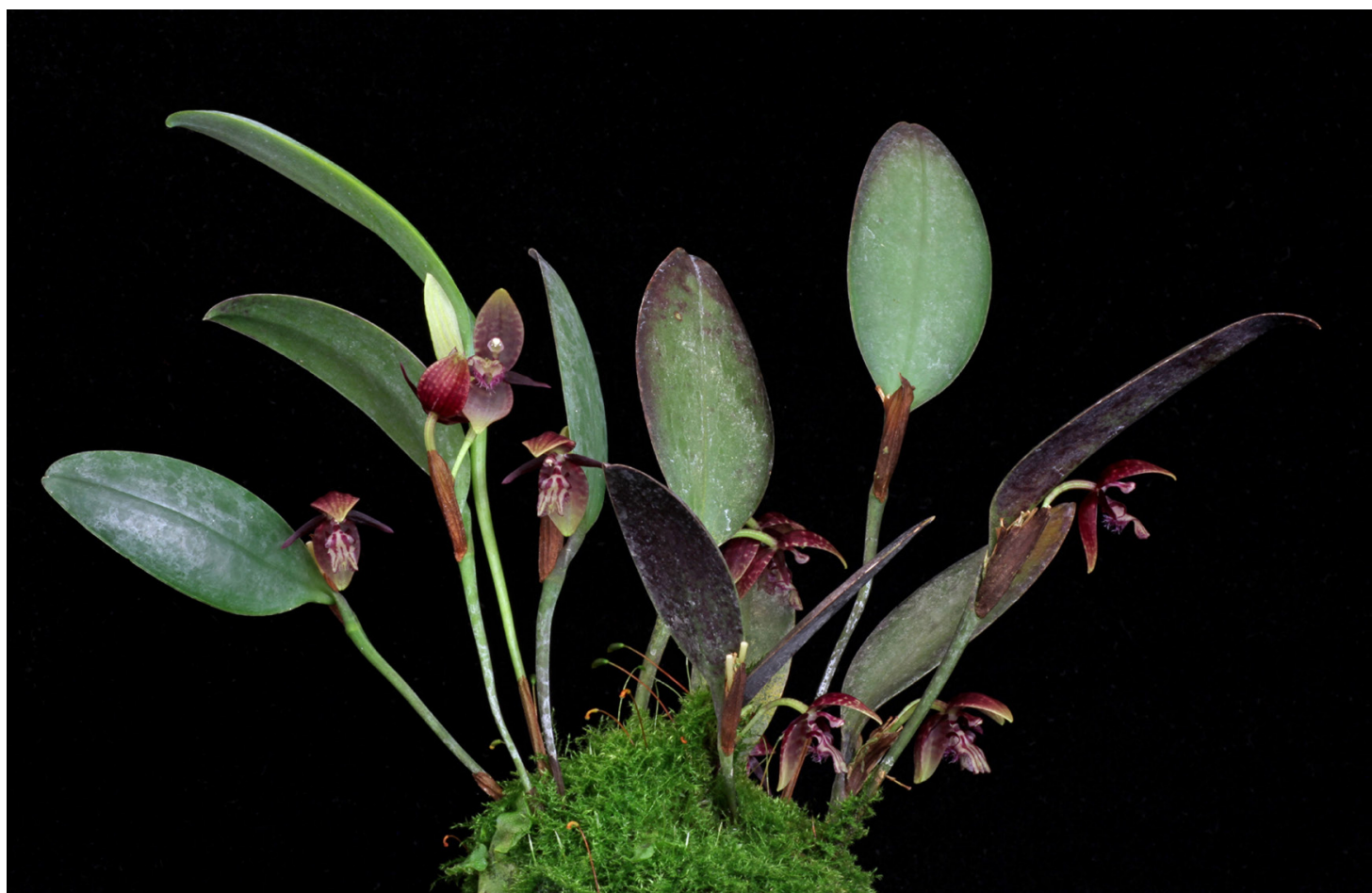

FIgURE 17. Whole plant of Pleurothallis jostii. Photograph by Ronald Hanko.

domed callus on the hypochile of $P$. trimeroglossa; the shorter hypochile at the articulation with the column foot in P. jostii.

Plant small, to $15 \mathrm{~cm}$ tall, epiphytic, caespitose. Roots fibrous. Ramicauls slender, terete, 4.0-7.9 cm long. Leaves erect, slightly arching, elliptical, subacute to acute, $4.1-8.5 \times 1.2-2.5 \mathrm{~cm}$, cuneate at base, fleshy, highly coriaceous, older leaves glaucous and waxy, with some purple coloration, petiole 4-13 mm long. Inflorescence single-flowered peduncle, from erect spathaceous bract, $0.9-1.7 \mathrm{~cm}$ long; ovary $7.0 \mathrm{~mm}$ long. Flowers 16-19 × 10-14 mm, resupinate. Dorsal sepal pale yellow-brown, heavily suffused with purplebrown, heaviest on outer surface, ovate, subacute, concave, 10.0-10.5 × 5.5-6.7 mm, glabrous, entire. Synsepal pale yellow-brown, heavily suffused with purple-brown, heaviest on outer surface, ovate-elliptic, subacute, concave, $10.0-10.5 \times 6.0-6.8 \mathrm{~mm}$, glabrous, entire. Petals deep purple, linear-lanceolate, somewhat oblique, acute 6-7 × 1.0-1.4 mm, glabrous, entire. Labellum white to pale cream mottled with purple, protruberant, five-lobed, 7.5-8.0 × 3.3-3.9 mm, apex divided into three acute lobes, shallowly sulcate below middle lobe, basal lobes rounded, fimbriate, revolute along front and rear edge, base short, terete, articulated on column foot. Column white lightly mottled with purple, slender, terete, arching, broadened at apex, 4.6-4.8 mm long, gently curved, smooth, pronounced column foot, hooded clinandrium, anther sub-apical.

Additional material studied: Ecuador. Purchased from Ecuagenera without collection data as $P$. talpinaria "purple", flowered in cultivation at Colorado College and identified as an undescribed species, M. Wilson \& J. Portilla PL0314, PL0517 and PL0782 (paratypes: COCO!).

ETymology: In honor of Lou Jost for his ongoing efforts to conserve Ecuadorian flora and fauna through Fundación EcoMinga.

This species has only been observed in the collection of Ecuagenera, or in collections containing plants derived from that commercial grower. As always with species described from collections, there is the risk that the plant represents an unintentional greenhouse hybrid. We do not believe that to be likely in this case, because the morphology is sufficiently 
distinct from P. talpinaria and P. trimeroglossa that it is almost certainly not a hybrid of those two species. And, since the floral morphology of these species is so unique, it is almost impossible to consider it a hybrid of $P$. talpinaria or $P$. trimeroglossa with a Pleurothallis species from any other subgenus.

While we assume that the species is from Ecuador, the global hobbyist and commercial exchange of species has completely obscured origins of Pleurothallis species in collections that are not associated with verified in situ occurrence data. Therefore, while the holotype of the species comes from an Ecuadorian collection and is deposited in an Ecuadorian herbarium, the species should not be added to the flora of Ecuador until the geographic origin of the species is located.

Conclusions. The three species, $P$. talpinaria, $P$. trimeroglossa and P. jostii are distinct in morphology, size and coloration. P. talpinaria and P. trimeroglossa probably occupy distinct, non-overlapping geographic ranges, $P$. talpinaria in Colombia (central and northeastern) and Venezuela (southwestern) and $P$. trimeroglossa in Peru, Ecuador (southeastern) and possibly Bolivia. However, confirmation of these ranges requires additional study and the geographic occurrence of $P$. jostii remains to be determined. The unique and fascinating labella of these species has implications for pollination mechanisms and we speculate that this group is pollinated by pseudocopulation. Testing of this hypothesis will require in situ observation.

ACKNOWLEDGEMENTS. The authors are grateful to Colorado College for research funding for Wilson and Dupree and provision of greenhouse and herbarium facilities; to Dr. Ron Hathaway of Colorado College for assistance with SEM; to Universidad de las Americas, Quito, Ecuador for support of Luis Baquero; to Ecuagenera and Mundiflora for access to plant collections; to members of the Portilla family for their warm hospitality; to Dale Borders, Ronald Hanko and Eric Hunt for the use of their photographs; to Adam Karremans and Diego Bogarín for instruction in preparation of LCDPs; and to the Editors of Lankesteriana and the anonymous reviewers for other suggestions to improve the manuscript.

\section{Literature Cited}

Archila, F. \& Chiron, G. R. (2015). Elaiophores, a labellum anatomic structure important in the pollination syndrome in Pleurothallis. Revista Guatemalensis, 18(1), 15-23.

Bennett, D. E. \& Christenson, E. A. (1993). Icones Orchidacearum Peruvianum. St. Louis: Missouri Botanical Gardens Press.

Calderón-Sáenz, E. (2011). Pleurothallis colossus: Pollination by Anthomyiid flies at El Refugio nature reservation. Orchids, 80(12), 740-743.

Dodson, C. H. \& Dodson, P. M. (1980). Orchids of Ecuador, Series 1, Fascicles 1-4, Icones Plantarum Tropicarum. Sarasota, FL, U.S.A.: The Marie Selby Botanical Gardens.

Dodson, C. H. \& Dodson, P. M. (1982). Orchids of Ecuador, Series 1, Fascicle 5, Icones Plantarum Tropicarum. Sarasota, FL, U.S.A.: The Marie Selby Botanical Gardens.

Dunsterville, G. C. K. \& Garay, L. A. (1961). Venezuelan Orchids Illustrated. Volume II. Amsterdam, The Netherlands: Andre Deutsch.

Duque H., Ó. (1993). Polinización en Pleurothallis. Orquideología, 19(1), 55-69.

Duque-Buitrago, C. A., Alzate-Quintero, N. F. \& Tupac Otero, J. (2014). Nocturnal pollination by fungus gnats of the Colombian endemic species, Pleurothallis marthae
(Orchidaceae: Pleurothallidinae). Lankesteriana, 13(3), 407-417.

Foldats, E. T. L. (1970). Flora de Venezuela: Orchidaceae. Volumen $X V$, Segunda parte. Caracas, Venezuela: Instituto Botánico.

Jiménez-Pérez, I. (2011). Nuevos registros de orquídeas de los bosques montanos de Bolivia. Parte I. Ecología en Bolivia, 46(1), 57-61.

Karsten, G. K.W. H. (1859). Florae Columbiae terrarumque adjacentium specimina selecta in peregrinatione duodecim annorum observata delineavit et descripsit (pp. 153-155). Berolini: Typis fratum unger. Recovered from http://www.biodiversitylibrary.org/ item/9238\#page/1/mode/1up

Luer, C. A. (1975a). Icones Pleurothallidinarum: Pleurothallis of Ecuador (Orchidaceae). Selbyana, 1(1), 56-100.

Luer, C. A. (1975b). Icones Pleurothallidinarum (Orchidaceae): Pleurothallis of Ecuador II. Selbyana, 1(2), 172-195.

Luer, C. A. (1975c). Icones Pleurothallidinarum (Orchidaceae): Pleurothallis of Ecuador III. Selbyana, 1(3), 220-303.

Luer, C. A. (1976). Icones Pleurothallidinarum: Miscellaneous species of Pleurothallis. Selbyana, 3(12), 38-201.

Luer, C. A. (1986). Icones Pleurothallidinarum III: 
Systematics of Pleurothallis. Monographs in Systematic Botany from the Missouri Botanical Garden, 20, 1-109.

Luer, C. A. (1998). Icones Pleurothallidinarum XVI. Systematics of Pleurothallis subgenera Crocodeilanthe, Rhynchopera and Talpinaria. Monographs in Systematic Botany from the Missouri Botanical Garden, 65, 1-122.

Luer, C. A. (2004). Icones Pleurothallidinarum XXVI. Pleurothallis subgenus Acianthera and three allied subgenera. A second century of new species of Stelis of Ecuador. Epibator, Ophidion, Zootrophion. Monographs in Systematic Botany from the Missouri Botanical Garden, 95, 1-265.

Luer, C. A. (2009). Miscellaneous new species in the Pleurothallidinae (Orchidaceae). Selbyana, 30(1), 1-71.

Luer, C. A. (2011). Miscellaneous new species in the Pleurothallidinae (Orchidaceae) excluding species from Brazil. Harvard Papers in Botany, 16(2), 311-360.

Luer, C. A. \& Thoerle, L. (2013). Miscellaneous new species in the Pleurothallidinae (Orchidaceae). Harvard Papers in Botany, 18(2), 173-196.

Pridgeon, A. M., Cribb, P.J., Chase, M. W. \& Rasmussen, F. N. (2005). Genera Orchidacearum. Volume 4. Epidendroideae (Part one), (385-390). Oxford, U.K.: Oxford University Press.

Pridgeon, A. M., Solano, R. \& Chase, M. W. (2001). Phylogenetic relationships in Pleurothallidinae (Orchidaceae): Combined evidence from nuclear and plastid DNA sequences. American Journal of Botany, 88, 2286-2308.

Reichenbach, H. G. (1886). Orchideae describuntur. Flora, 69(35), 547-562.

Schlechter, F. R. R. (1921). Repertorium Specierum Novarum Regni Vegetabilis Beih, 9: 78.

Schlechter, F. R. R. (1929). Figuren-Atlas zu den Orchideenfloren der südamerikanischen Kordillerenstaaten. In: Koeltz (Ed.), Feddes repertorium specierum novarum regni vegetabilis, Volumen 57. Berlin: Selbstverlag.

Schneider, M. (1958). Algunas especies Colombianas de Pleurothallis. Caldasia, 8(37): 99-120.
Schweinfurth, C. (1942). Orchidaceae Peruvianae. Botanical Museum Leaflets (Harvard University), 10, 173-216.

Schweinfurth, C. (1959). Orchids of Peru. Fieldiana Botany, 30(2), 261-531.

Schweinfurth, C. (1970). First Supplement to the Orchids of Peru. Fieldiana - Botany, 33, 1-85.

Tropicos. (2017). Missouri Botanical Garden, Missouri, USA. Available from http://www.tropicos.org/Home. aspx (Accessed on June 10 2017).

Wilson, M., Baquero, L., Dupree, K., Jiménez, M. M., LeBlanc, C. M., Merino, G., Portilla, J., Salas Guerrero, M., Tobar Suárez, F. \& Werner, J. D. (2016). Three new species of Pleurothallis (Pleurothallidinae; Orchidaceae) in subsection Macrophyllae-Fasciculatae from northern South America. Lankesteriana, 16(3), 349-366. Doi: http://dx.doi.org/10.15517/lank. v16i3.27314

Wilson, M., Belle, C., Dang, A., Hannan, P., Kenyon, C., Low, H., Stayton, T. \& Woolley, M. A. (2011). A phylogenetic analysis of the genus Pleurothallis, with emphasis on Pleurothallis subsection MacrophyllaeFasciculatae, using nuclear ITS and chloroplast DNA sequencing. Lankesteriana, 11(3), 369. Doi: http:// dx.doi.org/10.15517/lank.v11i3.18304

Wilson, M., Belle, C., Dang, A., Hannan, P., Kellogg, L., Kenyon, C., Low, H., Mochizuki, A., Nguyen, A., Sheade, N., Shan, L., Shum, A., Stayton, T., Volz, C., Vosburgh, B., Wellman, H. \& Woolley, M. A. (2013). A preliminary phylogenetic analysis of Pleurothallis sensu lato based upon nuclear and plastid sequences. Lankesteriana, 13(1-2), 139. Doi: http://dx.doi. org/10.15517/lank.v0i0.11568

Wilson, M., Frank, G.S., Jost, L., Pridgeon, A., VieiraUribe, S. \& Karremans, A. (2017). Phylogenetic analysis of Andinia (Orchidaceae: Pleurothallidinae) and a systematic re-circumscription of the genus. Phytotaxa, 295(2), 101-131. https://doi.org/10.11646/ phytotaxa.295.2.1 
LANKESTERIANA

LANKESTERIANA 17(2). 2017. (C) Universidad de Costa Rica, 2017. 